\title{
Fault orientations in the upper crust beneath an intraplate active zone in northern Egypt
}

\author{
A. K. Abdel-Fattah ${ }^{1,2}$, M. Fnais ${ }^{1}$, M. F. Abdelwahed ${ }^{3,4}$, A. El-Nekhely ${ }^{5}$, and W. Farid ${ }^{4}$ \\ ${ }^{1}$ King Saud University, Faculty of Science, Geology and Geophysics Department \\ ${ }^{2}$ SGS Research Chair on Natural Hazard \\ ${ }^{3}$ King Abdulaziz University, Geological Hazards Research Unit, 21589 Jeddah, Saudi Arabia \\ ${ }^{4}$ National Research Institute of Astronomy and Geophysics (NRIAG), 11421-Helwan, Egypt \\ ${ }^{5}$ Alexandria University, Faculty of Science, Physics Department, Alexandria, Egypt
}

(Received September 2, 2012; Revised December 1, 2012; Accepted December 13, 2012; Online published August 23, 2013)

\begin{abstract}
The present study aims to demarcate the active fault orientation in the upper crust of Dahshour Seismic Zone (DSZ) in Northern Egypt, and its relation to the regional tectonics. High-resolution earthquake relocations and focal mechanism solutions were determined using the double-difference location method and the forward modelling of the amplitude spectrum constrained with $P$-wave polarities, respectively. Up to 244 earthquakes were relocated by measuring differential travel times between events, as obtained from cross-correlation waveform analysis. The relocated hypocenters exhibited a seismogenic crust of 6-km thickness (most hypocenters have a focal depth of 18 to $24 \mathrm{~km}$ ). Incorporation of hypocentral distributions and focal mechanisms depicts distinct fault planes trending to the NW and ENE to EW, randomly distributed in the whole dislocation zone. The reactivation of these pre-existing faults is attributed to the northern Red Sea-Gulf of Suez rifts and the closure of the Neotethys, respectively; implying a potential impact of the regional tectonic process on the deformation acting in the upper crust of the local seismogenic zones of northern Egypt.
\end{abstract}

Key words: Earthquake relocation, double-difference technique, focal mechanism, North Egypt, seismotectonics.

\section{Introduction}

It is generally recognised that the study of intraplate earthquakes is a difficult task because their seismogenic faults may have minor features, strain rates are low, and large size earthquakes are infrequent (Dunn and Chapman, 2006). The accurate estimation of hypocenters and fault plane parameters for small-sized earthquakes recorded by local seismographic networks are essential to understand the ongoing geodynamical processes and the seismotectonics of active fault zones (Poupinet et al., 1984; Got et al., 1994; Dodge, 1996; Richards-Dinger and Shearer, 2000). Many techniques are used to determine earthquake locations individually or jointly (Thurber, 1983; Lienert et al., 1988; Pujol, 1988; Lahr, 2001). The double-difference (DD) algorithm (Waldhauser and Ellsworth, 2000; Waldhauser, 2001) estimates the residuals between the observed and calculated travel-time difference of two closely-spaced events at a single station by assuming similar ray paths propagating from the source zone to the station (Waldhauser and Ellsworth, 2000). This further cancels the common mode errors related to the receiver side structure resulting in no station corrections for the ray path outside the focal volume. The DD algorithm has been extensively used to improve the accuracy of hypocenter parameters along with

Copyright (C) The Society of Geomagnetism and Earth, Planetary and Space Sciences (SGEPSS); The Seismological Society of Japan; The Volcanological Society of Japan; The Geodetic Society of Japan; The Japanese Society for Planetary Sciences; TERRAPUB.

doi:10.5047/eps.2012.12.005 we can image the trends of blind active faults within the earth crust. The DD technique not only minimizes errors due to an inexact model of the velocity structure, but it also reduces the error between intra-event location by utilizing high-accuracy differential times derived from catalogue picks and/or waveform cross-correlation (Waldhauser and Ellsworth, 2000).

Intraplate earthquakes frequently occur in many source zones in Egypt (Abou Elenean, 2007), causing severe damage and loss of human life. Tectonically, the causes of intraplate earthquakes in Egypt are potentially attributed to the interaction between the African-Eurasian convergent plate margin and, in the northwest, the Red Sea divergent plate margin (Fig. 1). One of these zones is the Dahshour seismic zone (DSZ). The DSZ is located southwest of Cairo, the capital city of Egypt (Fig. 2). The zone is located between latitudes $29.30^{\circ}$ and $30^{\circ} \mathrm{N}$ and longitudes $30.30^{\circ}$ and $31.20^{\circ} \mathrm{E}$. Tectonically, the zone is located southeast of the convergent margin between the African and Eurasian plates and northwest of the divergent plate margin of the Red Sea rift. On a local scale, the tectonic process of intraplate earthquakes in Egypt is poorly understood. Owing to the complex tectonic processes in the region, the subsurface active faults in the zone may bring a potential seismic hazard to the Cairo metropolitan area. The frequencydependent attenuation of body waves, as determined by Abdel-Fattah (2009) using a coda normalization method, revealed that the upper crust of the study area is tectonically characterized by a high degree of heterogeneity. Moreover, 


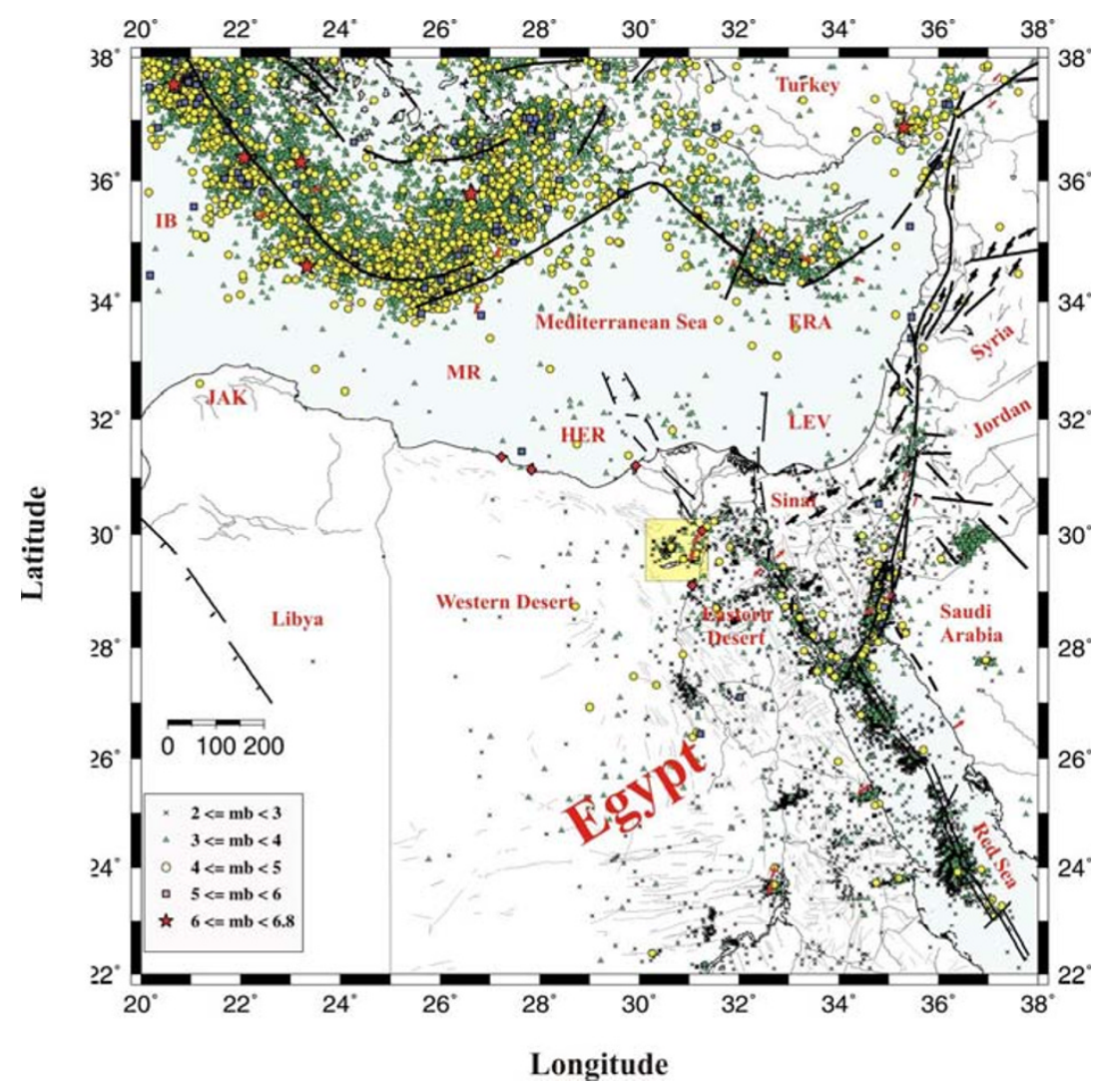

Fig. 1. Tectonic boundaries of the eastern Mediterranean region. Seismicity data $\left(2.0<m_{\mathrm{b}}<6.8\right)$ recorded by ENSN in the period $1997-2005$. Thick blue lines are a tentative Red Sea axial rift and its transform faults (Abou Elenean, 2007). The following acronyms denote: SY, Sinai hinge belt; TH, Themed Fault; WA, Wadi Araba; AEG-Aegean Sea; CY-Cyprus; ERA-Eratosthenes Seamount; FL-Florence; IB-Ionian Basin; MR, Mediterranean Ridge; LEV-Levantine Basin; LF-Levant Fault; HER-Herodotus Basin; JAK-Jebel Al Akhdar (Compiled after Abou Elenean and Hussein, 2008).

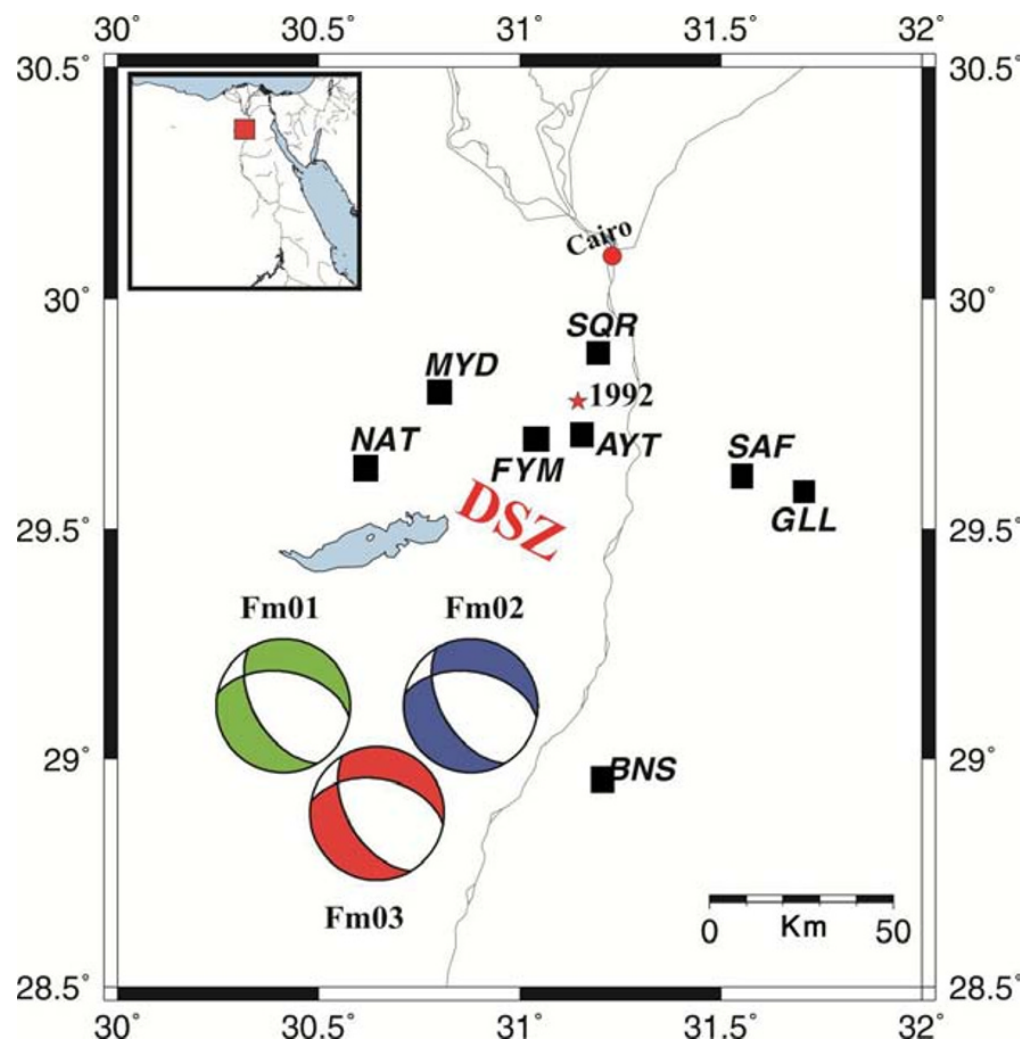

Fig. 2. Map showing the location of the 1992 earthquake (red stars), the seismic stations used in the present study (black squares), and DSZ-Dahshour Seismic Zone, Fm01 = El-Sayed et al. (1998), Fm02 = Hussein (1999), and Fm03 = Centroid Moment Tensor solution. 
the zone has experienced seismicity due to historical and recent earthquakes; two historical earthquakes have been reported, and a significantly-felt earthquake of moderate magnitude $M_{\mathrm{b}} 5.9$ occurred on October 12, 1992. Although the zone is, in general, characterized by a low to moderate seismicity, large earthquakes in an extensional regime may be expected.

The present study aims to determine the active fault orientation in the DSZ and its relation to the regional tectonics. For this purpose, we examine the spatial distribution of earthquake hypocenters to gain an insight into the orientation of seismogenic structures using the doubledifference algorithm for earthquake relocation, developed by Waldhauser and Ellsworth (2000). Besides, the interpretation of the double-difference hypocenter relocations is aided by matching with fault mechanism solutions for ten events, having a good signal-to-noise ratio, recorded by the local seismographic network during the period 2000-2005 in the respective region. The fault mechanisms were obtained using the forward modelling of the amplitude spectrum constrained with $P$-wave polarities, which was introduced by Zahradník et al. (2001). Earthquake relocations, fault mechanisms, and focal depth determinations, will enhance our understanding of the seismotectonics within the study area. The results will then be used to develop a database for seismic hazard assessment.

\section{Geologic and Tectonic Settings}

Egypt is located at the northeast corner of Africa, and is bounded by three active tectonic margins: the AfricanEurasian plate margin, the Red Sea plate margin, and the Levant-Dead Sea transform fault (Fig. 1). The highest rate of seismic activity takes place along the aforementioned margins. Meanwhile, part of the tectonic deformation is remotely transferred to excite seismic activity on the land, as is the case in the respective epicentral area, to rejuvenate the pre-existing NW-SE, WNW-ESE, E-W and WSW-ENE faults with a predominant normal faulting with a slight shear component (Moustafa, 2002; Abou Elenean, 2007). Detailed subsurface, and surface, studies indicate that the Miocene and post-Miocene extension in northern Egypt, due to the rift of Arabia away from Africa, formed a large number of NW-SE-oriented normal faults and rejuvenated the ENE-oriented faults in the Cairo-Suez district by dextral transtension (Moustafa et al., 1998). Based on the structural trend analysis, Brimich et al. (2011) defined the dominant structural trends in the study area as shown in Fig. 3. The rose diagram in Fig. 3 shows variable intensities and lengths for the aforementioned faults as the dominant tectonic trends affecting the epicentral area. The NW trend represents the most predominant trend direction and is known as the Eritrean, or African, trend (Said, 1962). The western desert of Egypt shows a series of observable positive magnetic anomalies of the NW trend as a result of the northward compressive force affecting the North African (Meshref, 1990). This trend initiated in the Red Sea and then developed to take place inland contemporaneously with the NE fault system trending.

Generally, the inland seismic activity lies conformably over three pre-existing fault trends in northern Egypt: the

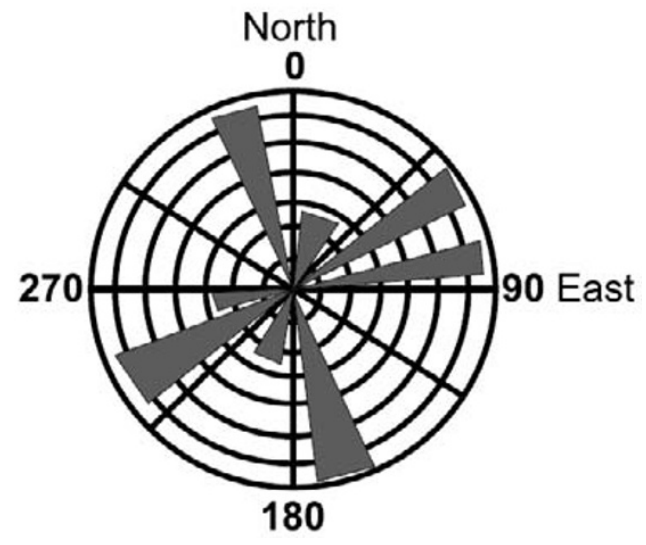

Fig. 3. Rose diagram shows analysed and plotted structure trends systems in the study area (after Brimich et al., 2011).

NW, EW, and NE faults as delineated by the precise earthquake locations recorded by ENSN and NEIC from 19972007 (Fig. 1). These fault trends were revealed by AbdelFattah and Badawy (2004). The first fault trends NW, which is mainly attributed to the Red Sea rifting, and is characterized by shallow earthquakes extending from the Gulf of Suez through the cities of Cairo and Alexandria (Kebeasy, 1990). The second fault trends NE, which is highly related to the Gulf of Aqaba-Dead Sea fault system. The third fault trends EW to ENE, which is related to the opening and closure of the Neotethys. Based on both the historical, and recent, seismicity, the study area is seismically active. Figure 4 shows the epicentres of historical and preliminarily instrumental earthquakes in and nearby the study area. It is obvious from Fig. 4 that the earthquakes are randomly distributed and they do not trace a distinct trend. However, different trends were suggested in the area from the fault plane solutions by El-Sayed et al. (1998): EW to ENE, NW-SE and E-W fault trends. These faults affect the basement, the overlying Mesozoic, and recent, sediments. These fault trends are assumed to be a result of the opening of the Tethys Sea and the Red Sea-Gulf of Suez rifting systems. The EW faults (oblique-slip movement with a subordinate right-lateral strike-slip component) are generally linked at depth with the NW-SE faults (pure dip-slip) in northern Egypt (Abou Elenean et al., 2010). The NW fault is believed to be responsible for the 1992 Cairo earthquake (El-Sayed et al., 1998; Hussein, 1999; Abdel-Fattah, 2003). For the 1992 aftershocks, the composite focal mechanism solutions by Abou Elenean et al. (2000) reflected the aforementioned fault planes. Focal mechanisms that computed for small- to moderate-sized earthquakes recorded by the Egyptian National Seismic Network (ENSN) indicate a dominant tension stress along the northeastern African corner, which changes to a dominant compression towards the Mediterranean Sea along the transition zone between the continental-oceanic crust. The tension axis trends ENEWSW along the Gulf of Suez, the Gulf of Aqaba, and the Red Sea rift, while trending NNE-SSW for mostly inland earthquakes (Bosworth and Stecker, 1997; Abou Elenean, 2007).

Stress information concerning regions within plate inte- 


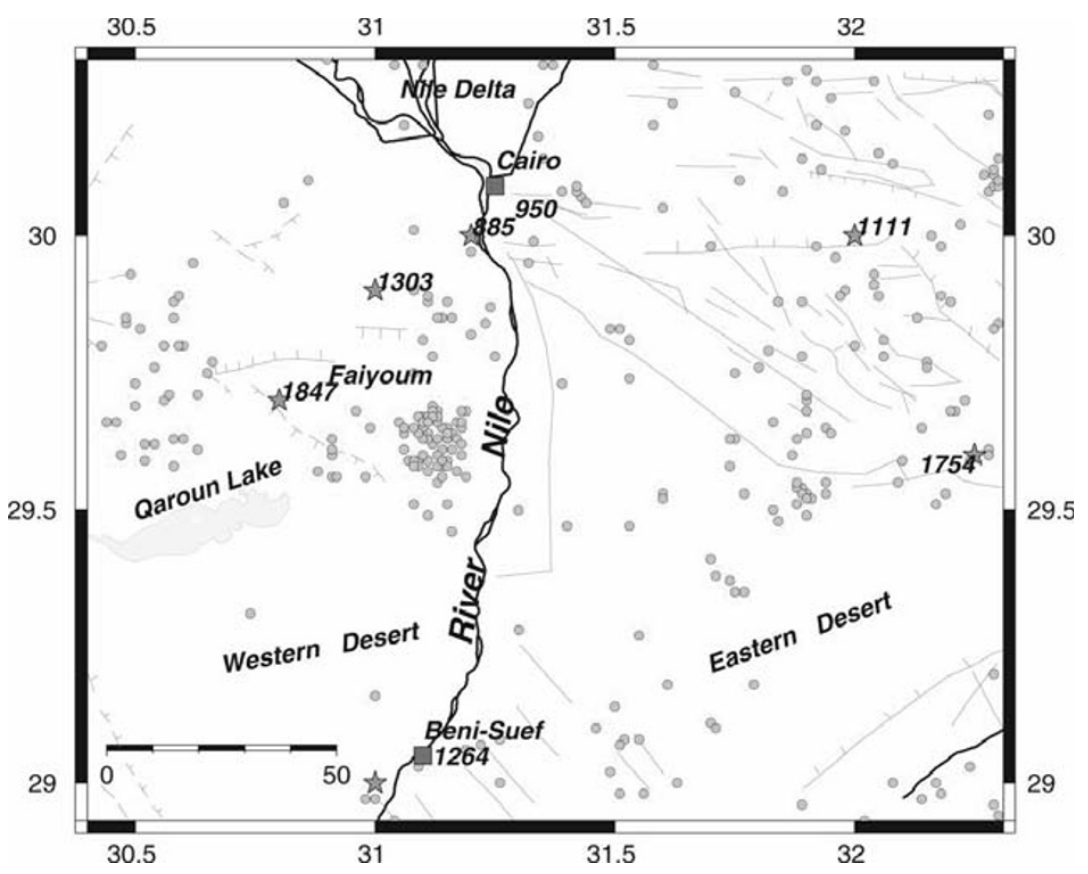

Fig. 4. Map showing the structural features, locations of the earthquakes (circles) and historical earthquakes (stars) in the study area and its vicinity.

riors is rare because of the lack of earthquake source mechanisms. Abou Elenean et al. (2000) showed that the stress regime affecting the epicentral area is a dominant extensional stress trending to NE-SW; generating normal faulting mechanisms with probabilities of a strike-slip component (Bosworth and Stecker, 1997). The stress field producing earthquakes in the epicentral area is considerably related to the complex relative motions between the African, the Arabian, and the Eurasian plates. Plate-motion slip rates have been accurately determined by recent GPS data (McClusky et al., 2000, 2003); a slip rate of $\sim 6 \mathrm{~mm} \mathrm{yr}^{-1}$ is associated with the northwestward motion of the African plate, whereas the northward motion of the Arabian plate has a rate of $\sim 18 \mathrm{~mm} \mathrm{yr}^{-1}$. The differential motion of Africa and Arabia relative to Eurasia is accommodated by the sinistral transpressional along the Dead Sea transform fault.

\section{Data Analysis and Results}

\subsection{Data use}

The data set of $P$ - and $S$-wave arrival times from 244 earthquakes having a magnitude between $M_{\mathrm{L}} 1.0$ and $M_{\mathrm{L}} 4.3$ are used in the present analysis. The earthquakes were recorded by the ENSN operated by the National Research Institute of Astronomy and Geophysics (NRIAG). The waveforms recorded by the stations within an epicentral distance of less than $100 \mathrm{~km}$ were used. The selected stations consisted of ten short-period $1-\mathrm{Hz}$ stations and a three-component broadband station (KOT). The sampling interval of these instruments is 100 samples per second. Arrival times of $P$ - and $S$-waves were chosen to decrease reading errors.

The local velocity models play an important role in the location of local events and the determination of focal mechanisms. Three velocity models are available in the study area and its vicinity. The first model of El-Hadidy
Table 1. Velocity model of El-Khrepy (2008).

\begin{tabular}{ccl}
\hline Depth $(\mathrm{km})$ & $V_{p}(\mathrm{~km} / \mathrm{s})$ & $V_{s}(\mathrm{~km} / \mathrm{s})$ \\
\hline 0 & $4.50 \pm 0.20$ & $2.60 \pm 0.20$ \\
1 & $5.10 \pm 0.15$ & $3.00 \pm 0.15$ \\
3 & $5.80 \pm 0.20$ & $3.40 \pm 0.2$ \\
5 & $6.05 \pm 0.15$ & $3.49 \pm 0.15$ \\
13 & $6.45 \pm 0.10$ & $3.74 \pm 0.10$ \\
20 & $6.89 \pm 0.15$ & $3.98 \pm 0.15$ \\
25 & $7.35 \pm 0.15$ & $4.27 \pm 0.15$ \\
30 & $7.88 \pm 0.08$ & $4.52 \pm 0.08$ \\
35 & $8.00 \pm 0.05$ & $4.60 \pm 0.05$ \\
40 & $8.10 \pm 0.05$ & $4.65 \pm 0.05$ \\
\hline
\end{tabular}

(1995), calculated using deep seismic sounding and gravity modeling, covered the area along Kottamia (north of eastern Desert). El-Khrepy (2001) derived a 3D velocity model in the Dahshour area using analogue data of $P_{\mathrm{g}}$ arrivals. ElKhrepy (2008) presented an averaged-velocity model for northeastern Egypt using $P$ - and $S$-arrival times of local earthquakes (Table 1).

\subsection{Hypocenter relocation}

$P$ - and $S$-wave arrivals were picked for earthquakes that occurred between 2000 and 2005. A total of $31607 P$ arrivals and $13692 S$-arrivals were used to relocate earthquakes in the Dahshour seismic zone. The availability of nearby stations permitted a reliable hypocenter location. The hypocenters were located using the hypo71 software (Lee and Lahr, 1972). The aforementioned onedimensional velocity models were used. The overall RMS error in the hypocenter estimates of the studied events is $0.16 \mathrm{~s}$. The earthquake locations used in the present study, and the seismic stations, are shown in Fig. 2. The velocity model derived by El-Khrepy (2008) reflects the smallest residuals in comparison with other two velocity models. 
To reduce uncertainty, we applied the double-difference earthquake location method (Waldhauser and Ellsworth, 2000). The double-difference residuals for pairs of earthquakes at each station are minimized by weighted leastsquares using the methods of conjugate gradients (LSQR) and singular value decomposition (SVD), while linking together all observed event-station pairs. Relocations were accomplished through two steps: firstly, we screened the data to optimize the linkage between events and minimize redundancy in the data set; secondly, we calculated the differential travel-time data using absolute locations. All arrivals were included in the relocation procedure by setting the maximum station-event distance to $200 \mathrm{~km}$. We also test the relocations for inter-event separations less than 5 and 10 $\mathrm{km}$, sequentially. A priori weights assigned for $P$ - and $S$ waves were 1.0 and 0.5 , respectively. Also, accurate $P$ - and $S$-wave differential arrival times between events were obtained by applying waveform cross-correlation in the time domain to minimize the errors, by an order of magnitude or more, in the case of earthquake pairs having the same rupture mechanism and a similar waveform (Schaff and Waldhauser, 2005).

The differential travel times are directly inverted to relocate earthquakes (e.g., Waldhauser and Ellsworth, 2000) or to improve the absolute arrival times at each station (e.g., Shearer et al., 2005). In the present analysis, travel times were differentially computed using the cross-correlation algorithm described in Schaff et al. (2004) and Schaff and Waldhauser (2005). We computed a total of about 1852 , and $864, P$ - and $S$-wave differential times, respectively, from pairs of waveforms yielding cross-correlation coefficients of 0.7 or larger. The cross-correlation waveform analysis was uniformly accomplished over the analysed stations on the basis of: (1) seismograms were filtered from 1.5 to $15 \mathrm{~Hz}$ (the instrument is reliable in this band); (2) correlations were made for both 1- and 2-s window lengths, for both $P$ - and $S$-wave windows with lags searched over $1 \mathrm{~s}$; and (3) $P$-wave windows are initially aligned on phase-pick data, and $S$-wave travel times are computed as 1.737 times the $P$-wave travel time as deduced by El-Khrepy (2008) across northern Egypt. 244 earthquakes were relocated by the double-difference relocation algorithm.

Because of the underestimate of the errors reported by LSQR, we checked the final locations by SVD to assess a true errors estimate (Waldhauser and Ellsworth, 2000). As the double-difference method minimizes errors due to an inaccurate velocity structure, the uncertainties of epicenter parameters and focal depth have been reduced by an average error of $0.3 \mathrm{~km}, 0.4 \mathrm{~km}$, and $0.3 \mathrm{~km}$, for latitude, longitude, and focal depth, respectively. In addition, the average of the root-mean-square value is $0.02 \mathrm{~s}$. Almost all events have a focal depth of $18-23 \mathrm{~km}$, reflecting a thin seismogenic layer of 6-km thickness. In fact, HypoDD acts as another earthquake location program based on Geiger's method (Geiger, 1910) insofar as station geometry is concerned. Therefore, we reduced the effect of error ellipse, the trade-off between focal depth and origin time, by the present distribution of station geometry that reflected the different vertical slowness of the rays. In addition, we used near stations and different arrival phases (e.g., $P_{\mathrm{g}}, P^{*}$,
$P_{\mathrm{n}}$, and $S_{\mathrm{g}}$ ) to minimize, and control, the trade-off between depth and origin time.

\subsection{Focal mechanism solutions}

Focal mechanisms of ten earthquakes were calculated using a recently-developed method by Zahradník et al. (2001), and Zahradník (2002). This method is based on the amplitude spectra of complete waveform data and the first-motion polarities, hereafter ASPO. The waveforms recorded by velocity sensors at the nearest local stations were employed. The take-off angles were calculated using the ray-method code ANGGRA (Jansky, 2001). In the ASPO method, the amplitude spectra were computed for waveforms of $60 \mathrm{~s}$ duration in the frequency range $1.0-2.0 \mathrm{~Hz}$. The spectra were then synthesized by the discrete wave-number method of Bouchon (1981), and Coutant (1989), using the velocity model of El-Khrepy (2008). A grid-search method was applied to three parameters: strike, dip, and rake angles. For each set of these model parameters, both the observed, and synthetic, spectra were normalized in order to put them on a comparable amplitude level. Band-pass filtering from 1.0 to $2.0 \mathrm{~Hz}$ was performed for the amplitude spectra. The normalization was performed by dividing the spectra by their average value computed for all components and frequencies at all available stations (taken over all stations, components and frequencies). The misfit at each station was calculated as a weighted L1 norm of the difference between the observed and synthetic amplitude spectra, and then summed over all stations, components and frequencies. The misfit function, introduced by Zahradník et al. (2001), not only reduces the undesired biasing effect of the largest amplitude at the near stations, but also normalizes the misfit values between 0 and 1 . Here, amplitude spectra solutions were constrained with first-motion polarities to obtain optimum solutions whose misfits are between $\pm 5 \%$. The procedure was repeated for a set of ten trial source depths. We started with a coarse search with a broad depth range $(5-40 \mathrm{~km})$, and then a fine search was focused around the minimum misfit value in a narrow depth range of 2-km intervals. To find the best-fit double-couple solution, the strike, dip, and rake were finely searched at 2-degree intervals. Finally, the scalar moment was retrieved with no grid-search procedure, since the problem is linear with respect to the scalar moment. Instead of grid searching, unit-moment synthetic spectra were calculated for the preferred mechanism and depth. The ratio between the observed and synthetic spectra (averaged over all the data points) yields the seismic moment (Zahradník et al., 2004). The SGRAPH program (Abdelwahed, 2012), with its implemented ASPO technique, is used to handle the processes of waveform analysis and focal mechanism estimation.

\section{Results \\ 4.1 Relocation}

The seismic events in the epicentral area were relocated with HypoDD using the modified velocity model deduced by El-Khrepy (2008). Figure 5 shows the distribution of the epicenters before, and after, relocation. It is obvious from Fig. 5 that the alignments of seismicity trend to the NW and ENE. The relocation of hypocentral parameters reflected more precise focal depths and helped to define the align- 


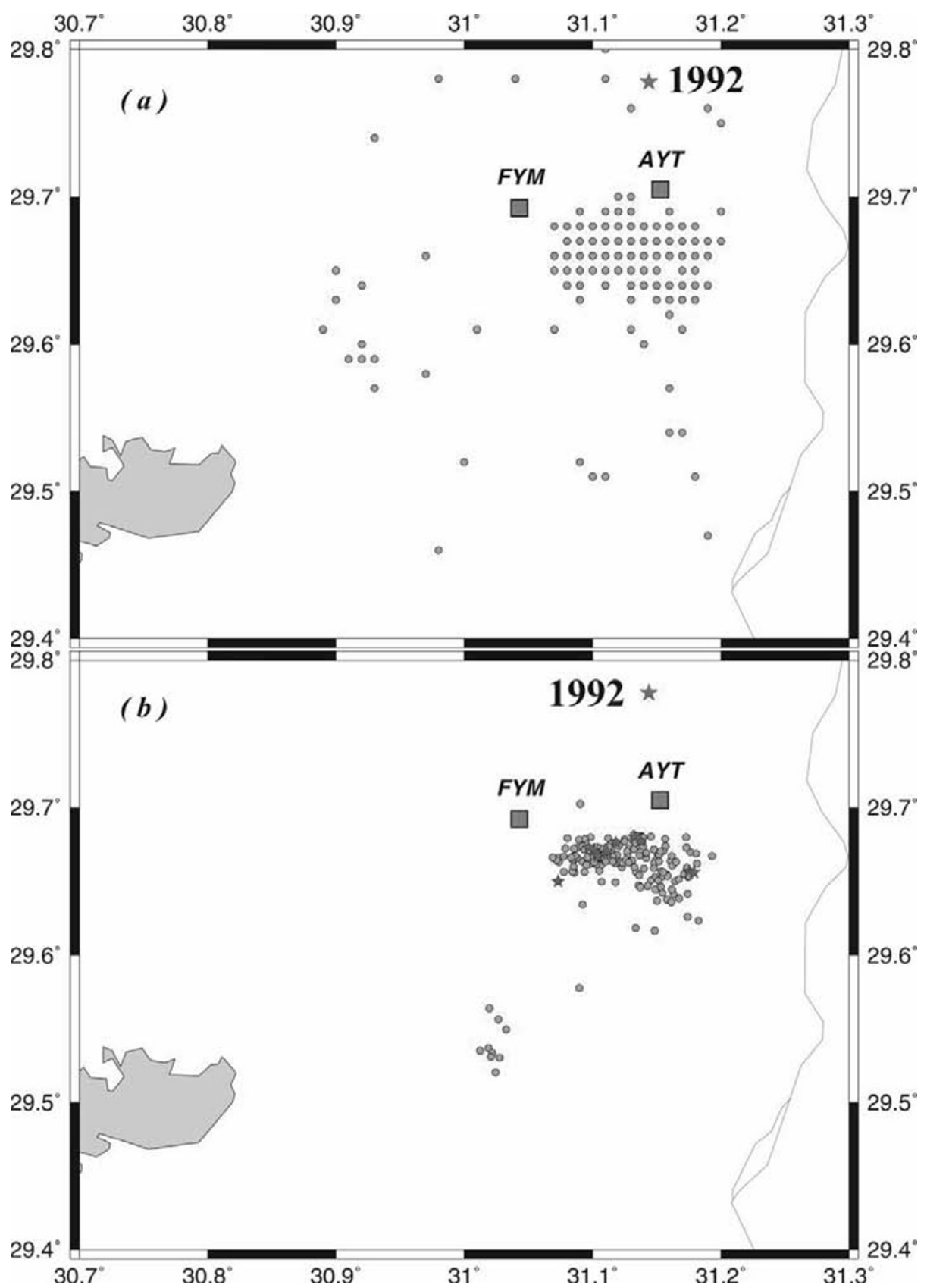

Fig. 5. Comparison of (a) preliminarily epicentral locations (circles) and (b) HypoDD epicentral relocations (circles) for the Dahshour earthquake source zone. The large and small stars are the epicentral locations of the 1992 earthquake and ten events listed in Table 2 , respectively.

ments of seismicity to the NW and the ENE to EW in the upper crust beneath the epicentral area, as shown in Fig. 6. The three-dimensional view of the hypocenters showed that the deformation of the upper crust occurred along a number of fault segments. The alignments of seismicity depict a number of fault segments trending to NW and ENE to EW. These fault segments are randomly distributed along the seismogenic layer of the study area (Fig. 6). The distinct fault planes are consistent with the focal mechanisms obtained from previous studies. The 1992 earthquake is proposed to locate on the ENE fault plane (Abou Elenean et al., 2000). The NW fault trend is believed to have produced the 1992 Cairo earthquake, as determined from directivity analysis by Abdel-Fattah (2003). We note that the focal depths of all the well-relocated events, as obtained by HypoDD, range from 18 to $24 \mathrm{~km}$, as shown in Fig. 7, exhibiting a seismogenic layer of $6-\mathrm{km}$ thickness. The results indicated that the seismogenic crust in the study area is considered to be the deepest active crust in Egypt. It is worth stressing that a two-dimensional gravity modelling study (Salem et al., 2004) depicted that the crust beneath the study area extends to a 33-km depth with an upper crust thickness of $22 \mathrm{~km}$.

\subsection{Focal mechanisms}

The focal mechanism solutions were determined using the ASPO technique. The hypocentral parameters, and the fault plane parameters, of ten seismic events of magnitude $\geq 2.5$ are shown in Table 2 . The focal mechanism solutions are shown in Fig. 6. An example of the variation of the amplitude-spectra misfit versus focal depths is shown in 


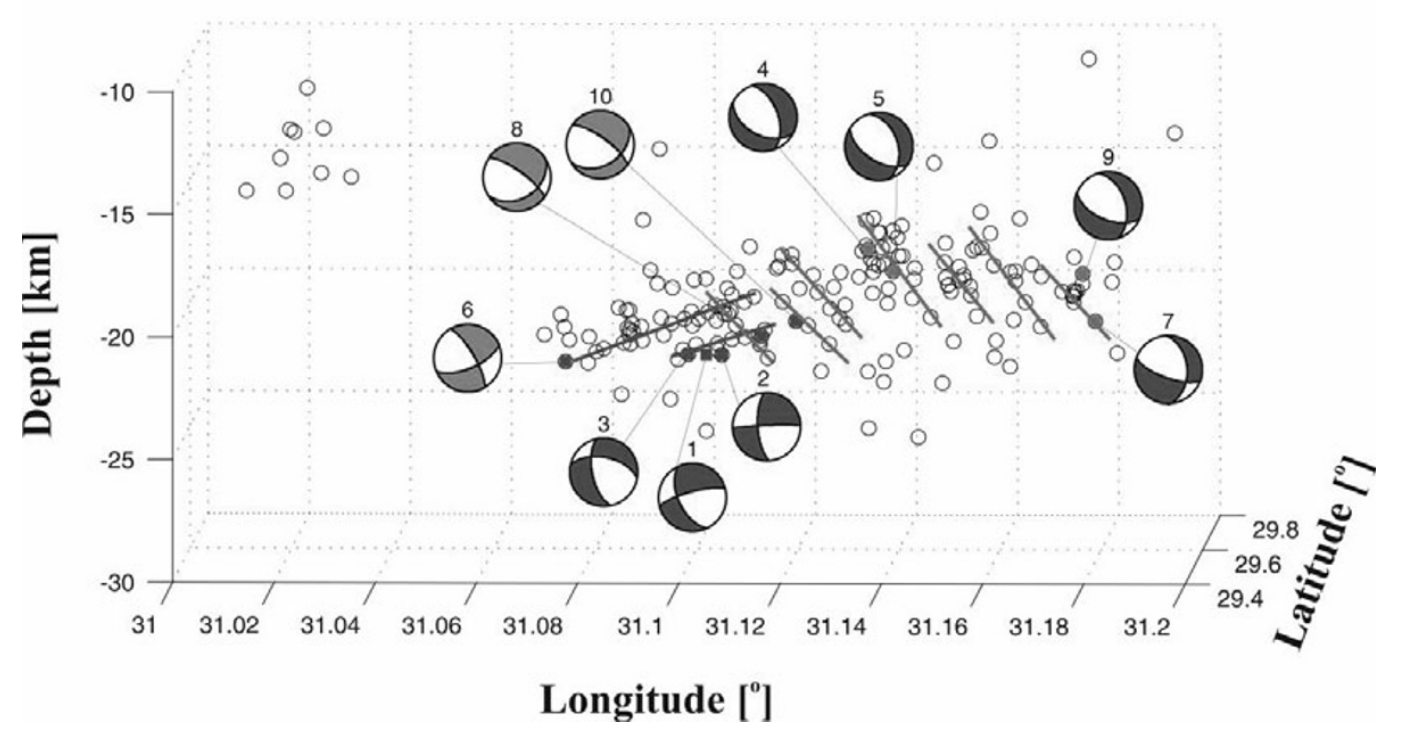

Fig. 6. Map view of HypoDD hypocentral relocations (open circles) associated with the focal mechanism solutions of ten events.

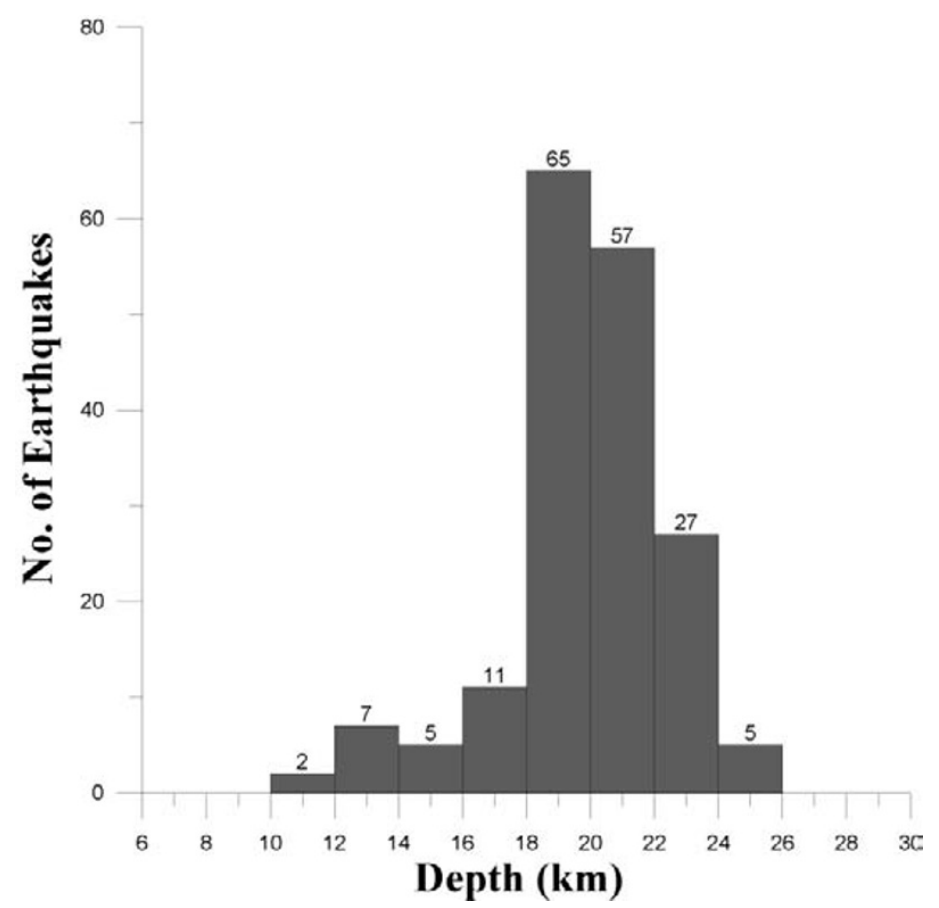

Fig. 7. Focal depth distribution of relocated earthquakes using HypoDD. The well-relocated hypocenters range from 18 to $24 \mathrm{~km}$ focal depths.

Fig. 8. Most of the events showed normal faulting mechanisms with strike-slip components compatible with the stress field for most inland earthquakes in northern Egypt which trends along NNE-SSW. Figure 9 shows an example of the observed, and synthetic, displacement amplitude spectra for the best focal mechanism of EV10 using the best crustal structure (El-Khrepy, 2008). The optimum focal depths obtained from the modeling of the amplitude spectrum are consistent with the focal depths determined from the relocation using the double-difference technique.

\section{Discussions and Conclusions}

Intraplate seismicity occurs in the vicinity of stress concentrators within pre-existing zones of weakness, where the faults are intersecting. These stress concentrators are structures where plate tectonic stresses can cause a localized buildup of stresses and, ultimately, earthquakes. These include intersecting faults, buried plutons, and rift pillows. The study of intraplate seismicity is difficult because the occurrence of large earthquakes are rare, and the thickness of the seismogenic layer is narrow. Talwani and Rajendran (1991) pointed out that most intraplate earthquakes occur around the intersections of faults, and, in general, not at the intersections themselves or very close to them. Data collected by the local-to-regional network monitoring of smallsize earthquakes are vital for understanding intraplate seismicity (Dunn and Chapman, 2006).

In the present study, two algorithms are used to investi- 
Table 2. Location and focal mechanism parameters of the studied events.

\begin{tabular}{|c|c|c|c|c|c|c|c|c|c|}
\hline \multirow[t]{2}{*}{ ID } & \multirow[t]{2}{*}{ Date \& Time } & \multirow[t]{2}{*}{ Lat. $\left[{ }^{\circ}\right]$} & \multirow[t]{2}{*}{ Long. $\left[{ }^{\circ}\right]$} & \multirow{2}{*}{$\begin{array}{c}\text { Depth } \\
{[\mathrm{km}]}\end{array}$} & \multirow[t]{2}{*}{$M_{\mathrm{L}}$} & \multicolumn{3}{|c|}{ Fault plane parameters } & \multirow[t]{2}{*}{$M_{\mathrm{o}}$ (N.m) } \\
\hline & & & & & & Strike & Dip & rake & \\
\hline EV01 & 20000124172849.00 & 29.671193 & 31.100700 & 22.688 & 3.1 & 255 & 76 & -145 & $0.31 \mathrm{E}+15$ \\
\hline EV03 & 20010529021225.28 & 29.673061 & 31.097116 & 22.575 & 2.8 & 281 & 54 & -145 & $0.95 E+14$ \\
\hline EV04 & 20010612134326.35 & 29.680221 & 31.132516 & 18.327 & 4.0 & 340 & 53 & -061 & $0.29 \mathrm{E}+16$ \\
\hline EV07 & 20030802100050.51 & 29.657063 & 31.175305 & 19.160 & 2.2 & 357 & 44 & -030 & $0.10 \mathrm{E}+14$ \\
\hline EV08 & 20040912080450.11 & 29.670074 & 31.111616 & 21.817 & 2.5 & 305 & 74 & -057 & $0.34 \mathrm{E}+14$ \\
\hline EV09 & 20041117223525.38 & 29.656180 & 31.177860 & 21.083 & 2.2 & 343 & 47 & -050 & $0.20 \mathrm{E}+14$ \\
\hline EV10 & 20050731161636.29 & 29.676533 & 31.118316 & 21.246 & 4.3 & 306 & 73 & -056 & $0.20 \mathrm{E}+16$ \\
\hline
\end{tabular}

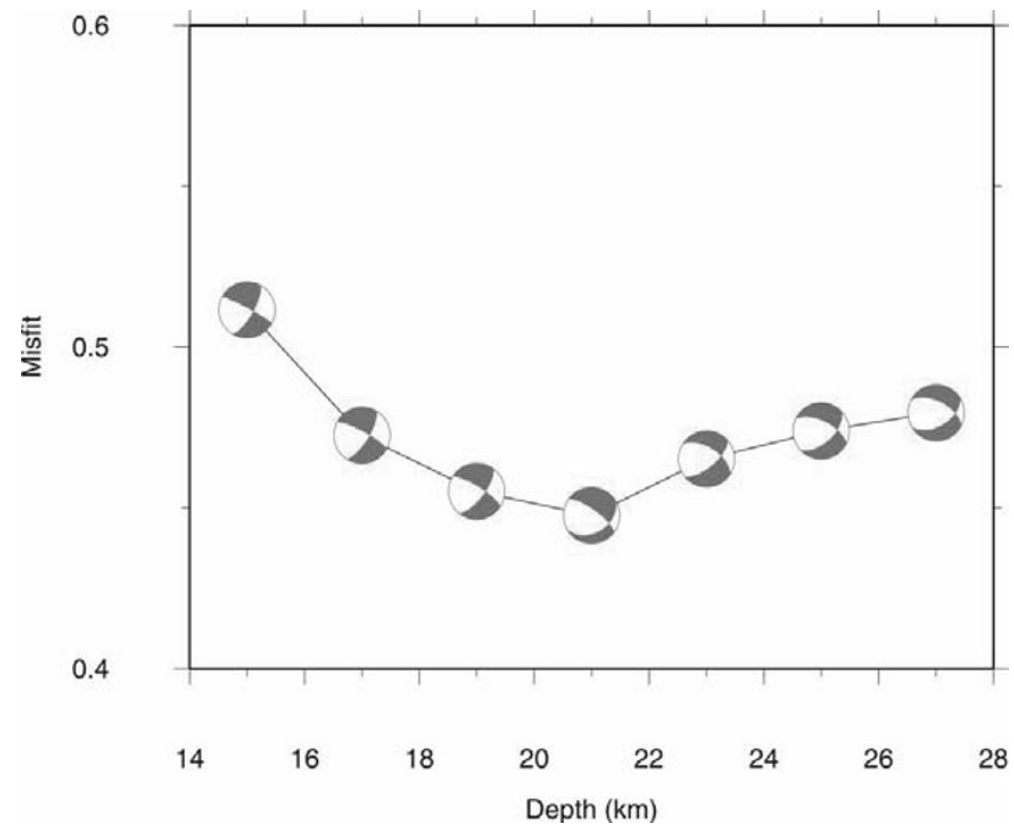

Fig. 8. Optimal best double-couple orientations for the event EV10 using the crustal structure of El-Khrepy (2008).

gate the fault orientations producing earthquakes in the upper crust beneath the study area. The identification of the NW, ENE to EW trending alignments of seismicity became clearer after relocations. We interpret the concentration of seismicity as being due to the concentration of stress at the intersection of the NW and the ENE to EW fault trends. The current results identify a number of active faults striking NW and ENE to EW. These faults are randomly distributed in space along the dislocation of the seismogenic layer that extends for a few kilometers; revealing that the complex tectonic process of the regional tectonic regime controlled the deformation in the upper crust of the study area. The aforementioned fault trends are consistent with the ruptured faults obtained for small-size earthquakes in northern Egypt as determined by Badawy and Abdel-Fattah (2001), AbdelFattah and Badawy (2002), and Abdel-Fattah et al. (2011).

The focal mechanism solutions indicated that earthquake activity within the dislocation zone is related to the movement along the NW and ENE to EW planes trending preexisting normal faults of a strike-slip component in response to the prevailing NE-SW tension. The results are consistent with that provided by available magnetic data, and land magnetic and aeromagnetic surveys, in the epicentral area, which reflected the main tectonic trends taking the directions NW and NE to ENE (Brimich et al., 2011). These tectonic trends are attributed to the relative tectonic motions between the African, Eurasian, and Arabian plates, as well as the key role of the Sinai subplate, where the study area is located southeast of the African-Eurasian convergent plate margin and northwest of the Red Sea divergent plate margin. Incorporation of the alignment of seismicity, the focal mechanism solutions, and the geologic and tectonic setting of the study area, the NW trending appears to correspond to the Red Sea rifting plate margin. On the other hand, the ENE to EW trending might be attributed to the African-Eurasian plate margin. The coupling of these tectonic movements plays the major tectonic role in the active deformation in the upper crust of northern Egypt.

The stresses which created the structure in northern Egypt are tension rather than compression as suggested by Shukri (1953) and Said (1962). Tensional and shear tectonic movements have affected the area in the form of basement joints and faults striking NW and EW. In addition, Quaternary sediments are also affected by EW and NE strik- 

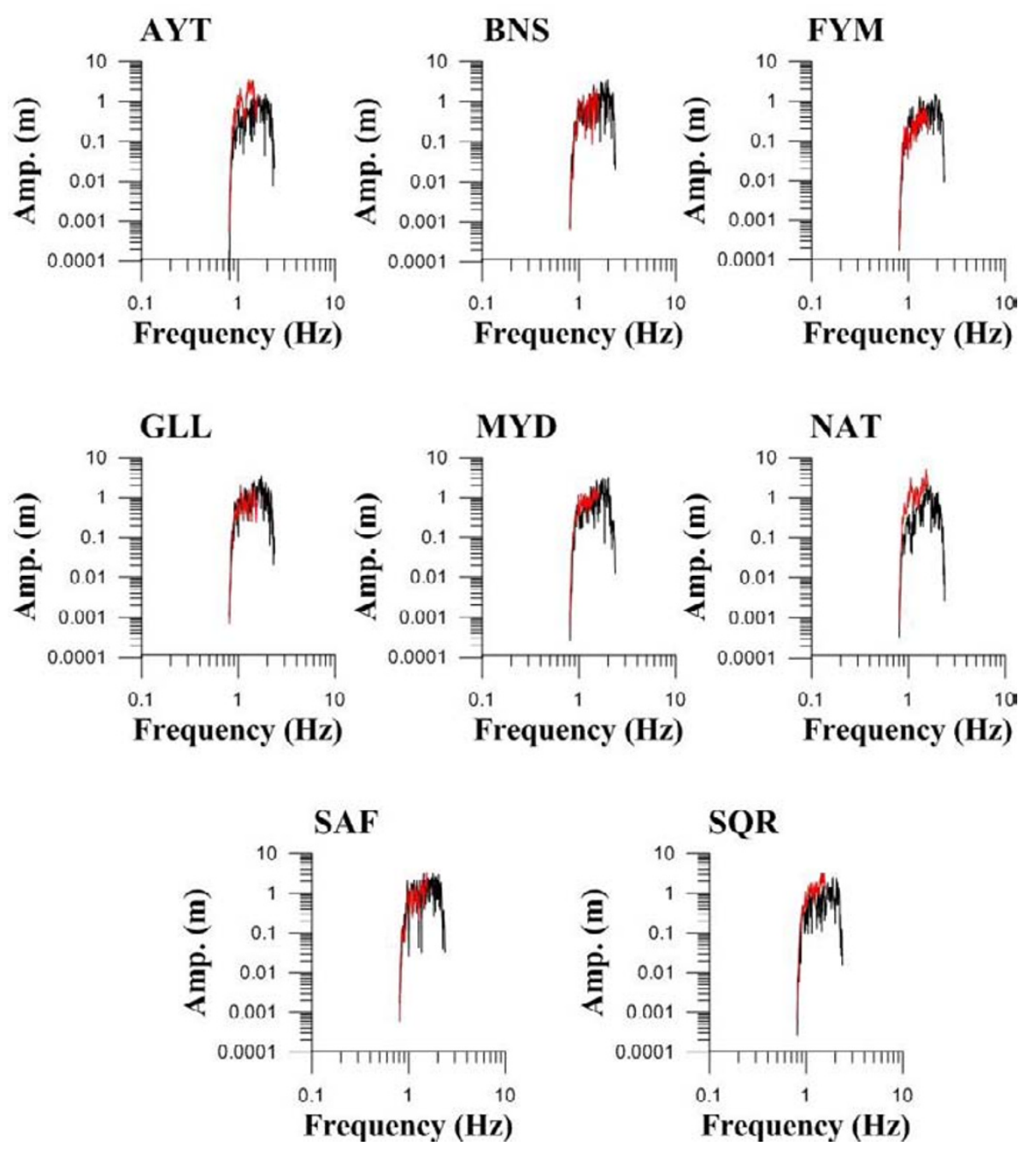

Fig. 9. Plot of the comparison between the observed (black line) and synthetic (red line) displacement amplitude spectra for the best focal mechanism of the event EV10 using the best crustal structure (El-Khrepy, 2008).

ing faults introducing a significant evidence of neotectonic activity in the epicentral area, as revealed by Kusky et al. (2011). The aforementioned trends are observable everywhere in northern Egypt, including north and central Sinai.

The results obtained from the relocation of hypocenters revealed a less-spatial resolution of the 1992 earthquake location due to poor station coverage. The 1992 earthquake is located toward the north, and far from the spatial distribution of recent seismicity by $15 \mathrm{~km}$. After the occurrence of the 1992 earthquake, the seismic stations were installed in the epicentral area, as shown in Fig. 2. Unfortunately, the stations were randomly installed on the basis of the imprecise location of the 1992 earthquake; most global seismic stations which recorded the event were located toward the north. The spatial distribution of seismicity obtained from the present study, with respect to the imprecise location of the 1992 earthquake, recommends an urgent optimization for the current source-station coverage in the epicentral area.

Acknowledgments. The first author acknowledges the King Saud University for making available time and facilities to accomplish this work. The authors acknowledge the assistance of many people at NRIAG who participated in the ENSN instrument deployment and preliminary data analyses. T. Okada, and anonymous referees, critically read the manuscript and provided us with helpful comments, which have improved the manuscript. Focal mechanism solutions and hypocenter relocation were computed using the ASPO package and HypoDD, respectively. Generic Mapping Tools (GMT) by Wessel and Smith (1995) is used to plot some of the figures in this manuscript. This work was supported by King Saud University, Deanship of Scientific Research, College of Science Research Centre.

\section{References}

Abdel-Fattah, A. K., An approach to investigate earthquake source processes, Acta Geophys., 51(3), 257-269, 2003.

Abdel-Fattah, A. K., Attenuation of body waves in the crust beneath the vicinity of Cairo Metropolitan area (Egypt) using coda normalization method, Geophys. J. Int., 176, 126-134, 2009.

Abdel-Fattah, A. K. and A. Badawy, Source process of the southeast BeniSuef, 620 northern Egypt earthquake using Empirical Green's Function technique, J. Seismol., 6(2), 153-161, 2002.

Abdel-Fattah, A. K. and A. Badawy, Source characteristics and tectonic implications of moderate earthquake, northeastern Cairo Prefecture, Acta Geophys., 52(1), 29-43, 2004.

Abdel-Fattah, A. K., K. Y. Kim, and M. S. Fnais, Slip distribution model of two small-sized inland earthquakes and its tectonic implication in north-eastern desert of Egypt, J. Afr. Earth Sci., 61(4), 296-307, 2011.

Abdelwahed, M. F., SGRAPH (SeismoGRAPHer): Seismic waveform analysis and integrated tools in seismology, Comput. Geosci., 40, 153$165,2012$. 
Abou Elenean, K. M., Focal mechanisms of small and moderate size earthquakes recorded by the Egyptian National Seismic Network (ENSN), Egypt, NRIAG J. Geophys., 6(1), 119-153, 2007.

Abou Elenean, K. M. and H. M. Hussein, The October 11, 1999 and November 08, 2006 Beni Suef Earthquakes, Egypt, Pure Appl. Geophys., 165(7), 1391-1410, 2008.

Abou Elenean, K. M., H. M. Hussein, A. S. Abu El-Ata, and M. I. Ezzeldien, Seismological aspects of the Cairo earthquake, 12th October 1992, Ann. Di Geofisica, 43(3), 485-504, 2000.

Abou Elenean, K. M., A. M. E. Mohamed, and H. M. Hussein, Source parameters and ground motion of the Suez-Cairo shear zone earthquakes, Eastern Desert, Egypt, Nat. Haz., 52(2), 431-451, 2010.

Badawy, A. and A. K. Abdel-Fattah, Source parameters and fault plane determinations of the 28 December 1999 northeastern Cairo earthquakes, Tectonophysics, 343, 63-77, 2001.

Bosworth, W. and M. R. Stecker, Stress field changes in the Afro-Arabian rift system during the Miocene to Recent period, Tectonophysics, 278, 47-62, 1997.

Bouchon, M., A simple method to calculate Green's functions for elastic layered media, Bull. Seismol. Soc. Am., 71, 959-971, 1981.

Brimich, L., A. Khalil, P. Kord'Ik, M. Mekkawi, M. El-Bohoty, M. Refai, and A. Abdel Kader, Active subsurface structures at Fayoum-Cairo district, Northern Western Desert, Egypt, as deduced from magnetic data, Contrib. Geophys. Geod., 41(4), 329-351, 2011.

Coutant, O., Program of Numerical Simulation AXITRA, Res. Rep. LGIT, Grenoble, 1989 (in French).

Dodge, D., Microearthquake studies using cross-correlation derived hypocenters, Ph.D. thesis, 146 pp., Stanford University, 1996.

Dunn, M. M. and M. C. Chapman, Fault orientation in the eastern Tennessee seismic zone: A study using the double-difference earthquake location algorithm, SRL, 77(4), 494-504, 2006.

El-Hadidy, S., Crustal structure and its related causative tectonics in northern Egypt using geophysical data, Ph.D. thesis, Ain Shams University, Egypt, 1995.

EL-Khrepy, S. A. F., Tomographic Modeling of Dahshour Area Local Earthquakes, Northern Egypt, M.Sc. thesis, Ain Shams University, Egypt, 2001

EL-Khrepy, S. A. F., Detailed Study of the Seismic Waves Velocity and Attenuation Models using Local Earthquakes in the Northeastern Part of Egypt, Ph.D. thesis, Mansoura University, Egypt, 2008.

El-Sayed, A., R. Arvidsson, and O. Kulhanek, The 1992 Cairo earthquake: A case study of a small destructive event, J. Seismol., 2, 293-302, 1998.

Geiger, L., Herdbestimmung bei erdbeden aus den ankunfzeitzen, $K$. Gessel. Wiss. Goett., 4, 331-339, 1910.

Got, J. L., J. Fréchet, and F. W. Klein, Deep fault plane geometry inferred from multiplet relative relocation beneath the south flank of Kilauea, $J$. Geophys. Res., 99, 15375-15386, 1994.

Hussein, H. M., Source process of the October 12, 1992 Cairo earthquake, Ann. Geophys., 42(4), 665-674, 1999.

Jansky, J., Ray-method calculations of the travel times and také-off angles in gradient models, program ANGGRA, Res. report, Faculty of Math. and Phys., Charles University, Prague, 2001.

Lahr, J. C., HYPOELLIPSE Y2K ver. 3.9: A computer program for determining local earthquake hypocentral parameters, magnitude and first motion pattern, personal communication, 2001.

Lee, W. and S. Lahr, HYPO71, a computer program for determining hypocenter, magnitude and first motion of local earthquakes, US Geol. Surv., Open file report, 1972.

Lienert, B., E. Berg, and L. Frazer, HYPOCENTER, an earthquake location method using centred, scaled and adaptively least squares, Bull. Seismol. Soc. Am., 76, 771-783, 1988.

Kebeasy, R. M., Seismicity, in Geology of Egypt, edited by R. Said, pp. 5159, A. A. Balkerma, Rotterdam, 1990.

Kusky, T. M., T. M. Ramadan, M. M. Hassaan, and S. Gabr, Structural and tectonic evolution of El-Faiyum depression, north western desert, Egypt based on analysis of landsat ETM+, and SRTM data, J. Earth Sci., 22(1), 75-100, 2011.

McClusky, S., S. Balassanian, A. Barka, C. Demir, S. Ergintav, I. Georgiev, O. Gurkan, M. Hamburger, K. Hurst, H. Kahle, K. Kastens, G.
Kekelidze, R. King, V. Kotzev, O. Lenk, S. Mahmoud, A. Mishin, M. Nadariya, A. Ouzounis, D. Paradissis, Y. Peter, M. Prilepin, R. Reilinger, and I. Sanli, Global Positioning System constraints on plate kinematics and dynamics in the eastern Mediterranean and Caucasus, $J$. Geophys. Res., 105, 5695-5719, 2000.

McClusky, S., R. Reilinger, S. Mahmoud, D. Ben Sair, and A. Tealeb, GPS constraints on Africa (Nubia) and the Arabia plate motions, Geophys. $J$. Int., 155, 126-138, 2003.

Meshref, W., Tectonic framework, in The Geology of Egypt, edited by R. Said, pp. 113-155, A.A. Balkerma, Rotterdam, Netherlands, 1990.

Moustafa, A., Controls on the geometry of transfer zones in the Suez rift and northwest Red Sea: Implications for the structural geometry of rift systems, AAPG Bull., 86(6), 979-1002, 2002.

Moustafa, A., R. El-Badrawy, and H. Gibali, Pervasive E-ENE oriented faults in northern Egypt and their effect on the Development and inversion of prolific sedimentary basis. Proceedings of 14th petroleum conference, vol. 1. Egyptian General Petroleum Corporation, pp. 51-67, 1998

Poupinet, G., W. L. Ellsworth, and J. Frechet, Monitoring velocity variations in the crust using earthquake doublets: An application to the Calaveras fault, California, J. Geophys. Res., 89, 5719-5731, 1984.

Pujol, J., Comments on the joint determination of hypocenters and station corrections, Bull. Seismol. Soc. Am., 78, 1179-1189, 1988.

Richards-Dinger, K. B. and P. M. Shearer, Earthquake locations in southern California obtained using source-specific station terms, J. Geophys. Res., 105, 10939-10960, 2000.

Said, R., The Geology of Egypt, Elsevier Pub. Co., New York, 337 p., 1962. Salem, S. R., S. O. El-Khateeb, and M. F. Mousa, Structure and Evolution of North African Passive Margin Crust: As Inferred from 2-D Gravity Modeling of Nile Delta and its Surrounding Areas, Egypt, EGS J., 2(1), 17-29, 2004.

Schaff, D. P. and F. Waldhauser, Waveform cross-correlation-based differential travel-time measurements at the Northern California Seismic Network, Bull. Seismol. Soc. Am., 95, 2446-2461, 2005.

Schaff, D. P., G. H. R. Bokelmann, W. L. Ellsworth, E. Zanzerkia, F Waldhauser, and G. C. Beroza, Optimizing correlation techniques for improved earthquake location, Bull. Seismol. Soc. Am., 94, 705-721, 2004.

Shearer, P. M., E. Hauksson, and G. Lin, Southern California hypocenter relocation with waveform cross-correlation, Part 2: Results using source-specific station terms and cluster analysis, Bull. Seismol. Soc. Am., 95(3), 904-915, 2005.

Shukri, N. M., The geology of the desert east of Cairo, Bull. Inst. Desert d'Egypt, 3(2), 89-105, 1953.

Talwani, P. and K. Rajendran, Some seismological and geometric features of intraplate earthquakes, Tectonophysics, 186, 19-41, 1991.

Thurber, C. H., Earthquake locations and three-dimensional crustal structure in the Coyote lake area, Central California, J. Geophys. Res., 88 , 8226-8236, 1983.

Waldhauser, F., HypoDD: A program to compute double-difference hypocenter locations, U.S. Geologic Survey Open-File Report, 2001.

Waldhauser, F. and W. L. Ellsworth, A double-difference earthquake location algorithm: Method and application to the Hayward fault, Bull. Seismol. Soc. Am., 90, 1353-1368, 2000.

Wessel, P. and W. H. F. Smith, New version of the generic mapping tools released, Eos Trans. AGU, 76, 329, 1995.

Zahradník, J., Modeling the Skyros island, Aegean Sea $M w=6.5$ earthquake of July 26, 2001, Studia Geoph. et Geod., 46, 753-771, 2002.

Zahradník, J., J. Jansky, and K. Papatsimpa, Focal Mechanisms of Weak Earthquakes from Amplitude Spectra and Polarities, Pure Appl. Geophys., 158, 647-665, 2001.

Zahradník, J., J. Jansky, E. Sokos, A. Serpetsidaki, H. Lyon-Caen, and P. Papadimitriou, Modeling the $M_{\mathrm{L}} 4.7$ Mainshock of the February-July 2001 Earthquake Sequence in Aegion, Greece, J. Seismol., 8, 247-257, 2004

A. K. Abdel-Fattah (e-mail: ali_kamel@yahoo.com), M. Fnais, M. F. Abdelwahed, A. El-Nekhely, and W. Farid 